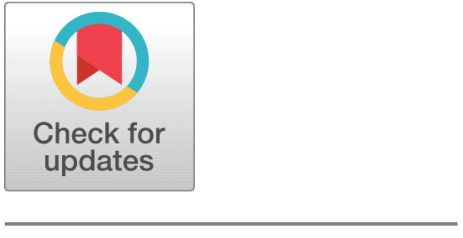

OPEN ACCESS

Received: 22.12 .2020

Accepted: 31.03 .2021

Published: 26.04 .2021

Citation: Ma. Danica Ines Ramil , Angelica May DC. Mendoza, Rhian Jaymar D. Ramil (2021) Assessment on the Physicochemical and Phytochemical Properties, Nutritional and Heavy Metal Contents, and Antioxidant Activities of Hylocereus polyrhizus Peel from Northern Philippines. Indian Journal of Science and Technology 14(14): 1097-1104. https://doi.org/ 10.17485/IJST/v14i14.2286

* Corresponding author.

Tel: (+63) 9277339569 jaymar_1329@yahoo.com.ph

Funding: None

Competing Interests: None

Copyright: (c) 2021 Ma. Danica Ines Ramil et al. This is an open access article distributed under the terms of the Creative Commons Attribution License, which permits unrestricted use, distribution, and reproduction in any medium, provided the original author and source are credited.

Published By Indian Society for Education and Environment (iSee)

ISSN

Print: 0974-6846

Electronic: 0974-5645

\section{Assessment on the Physicochemical and Phytochemical Properties, Nutritional and Heavy Metal Contents, and Antioxidant Activities of Hylocereus polyrhizus Peel from Northern Philippines}

\author{
Ma. Danica Ines Ramil ${ }^{1}$, Angelica May DC. Mendoza1, \\ Rhian Jaymar D. Ramil ${ }^{1 *}$ \\ 1 Assistant Professors, Pharmacy Department, Mariano Marcos State University, City of \\ Batac, Ilocos Norte, 2906, Philippines. Tel.: (+63) 9277339569
}

\section{Abstract}

Background/Objectives: In the Philippines, Hylocereus polyrhizus is gaining upsurge interest due to its potential health benefits. Aside from the edible fruit pulp, various products from its peel are being developed, and claimed as health boosters. Thus, this study was conducted to assess the physicochemical characteristics, phytochemical constituents, nutritional and heavy metal contents and antioxidant activity of the peel of $\mathrm{H}$. polyrhizus. Methods/Statistical analysis: Physicochemical and phytochemical screening were conducted following established protocols. Nutritional value and trace metals were measured with food analytical standard methods. Antioxidant activity was estimated using 2, 2-diphenyl-1-picrylhydrazyl (DPPH) and ferric reducing capacity (FRC) assays. Statistical analyses were carried out for DPPH and FRC assays using GraphPad Prism. Findings: Results showed that $H$. polyrhizus peel contains alkaloids, coumarins, flavonoids, phenols, and triterpenoids. Trace amounts of arsenic (0.022 $\mathrm{mg} / \mathrm{kg})$, lead $(0.887 \mathrm{mg} / \mathrm{kg})$, cadmium $(0.068 \mathrm{mg} / \mathrm{kg})$ and chromium $(0.225 \mathrm{mg} / \mathrm{kg})$ were detected which were all within the acceptable limit set by the WHO for herbal materials. H. polyrhizus peel contained $6.72 \%$ moisture, $14.7 \%$ ash, $0.526 \%$ total fat, $0.226 \%$ saturated fat, $3.73 \%$ total sugar, $4.28 \%$ crude protein, $73.8 \%$ total carbohydrate, and $63.2 \%$ total dietary fiber. Other nutrients detected are macronutrients such as $\mathrm{K}>\mathrm{Ca}>\mathrm{Mg}>\mathrm{Na}$, micronutrients $\mathrm{Mn}>\mathrm{Fe}$, and Vitamin $\mathrm{C}$. Moreover, it exhibited remarkable antioxidant activity in terms of FRC assay and DPPH assay $\left(\mathrm{IC}_{50}=986.8 \mu \mathrm{g} / \mathrm{mL}\right)$. The present study results showed that $H$. polyrhizus peel could be used as a potentially rich source of nutrients and natural antioxidants. Thus, it can be developed as an ingredient for food and health products. Novelty/Applications: The preliminary data obtained provide information that could support the development of products from dragon fruit peel. The conversion of these wastes into utilizable natural health products would help in reducing environmental problems 
associated with processing waste disposal.

Keywords: Antioxidant; Dragon Fruit Peel; Hylocereus polyrhizus; Phytochemical Screening; Nutritional Content; Heavy Metals

\section{Introduction}

Hylocereus polyrhizus, also known as pitaya or dragon fruit, is an introduced crop in the Philippines that have gained popularity in research and development as an alternative crop in addressing economic growth in the country ${ }^{(1)}$. Morphologically, the fruit of $H$. polyrhizus is oblong with a pink to red peel and large green scales and its pulp is colored red to intense purple ${ }^{(2)}$. Aside from being a rich source of phytochemicals and nutrients that could provide many beneficial effects when consumed fresh, it is also utilized to develop and formulate food and health products ${ }^{(2)}$. The cultivation of $H$. polyrhizus is increasing dramatically especially in the Philippines' northern region for the past few years owing to the overwhelming demand from local markets ${ }^{(3)}$. Besides, $H$. polyrhizus is believed to be the favorite of local consumers due to its sweet taste and attractive color compared to other species or varieties ${ }^{(3)}$. However, the consumption of $H$. polyrhizus gained significant increase in waste material, especially the peels. As a result, this waste material can cause detrimental effects in the environment. Annually, the Philippines generate approximately 6.53 million tons of fruit and vegetable waste ${ }^{(4)}$. Therefore, to keep pace with the zero-waste management system, it is essential to utilize the $H$. polyrhizus peel for food and natural health-based products including nutraceuticals and cosmeceuticals.

Since there is a growing consumer awareness on the safety, and health issues concerning the use of food and natural health products which includes nutraceuticals, food supplements, cosmeceuticals, and among others, there is a need to establish the qualitative and quantitative values that carry an assurance of quality, efficacy, safety, and reproducibility of raw materials in the product development. Notably, literature suggests that geographical locations have considerable impact on the levels of phytochemicals, proximate nutrients, selected minerals and conversely their biological activities ${ }^{(5)}$. This study is an exerted effort in the research and development to facilitate the further expansion of the emerging industry of dragon fruit in the northern Philippines which is constrained by the lack of standardization in fruit quality and product development ${ }^{(1)}$. Therefore, the aim of the present work is to determine the physicochemical characteristics, phytochemical constituents, traces of heavy metals, proximate composition, minerals and vitamin content, and antioxidant activities of $H$. polyrhizus peel obtained in Ilocos Norte, Philippines.

\section{Materials and Methods}

\subsection{Chemicals and reagents}

2, 2-diphenyl-1-picrylhydrazyl (DPPH), 1,10-phenanthroline monohydrate, ferric chloride and ascorbic acid were obtained from Sigma-Aldrich (Germany/USA). All other chemicals were of analytical grade and supplied from other commercial sources.

\subsection{Plant material}

An approximate of 30 kilograms of $\mathrm{H}$. polyrhizus fruits were purchased in Batac, Ilocos Norte. Fruit peels were separated from the edible pulps. The peels were oven-dried at $35^{\circ} \mathrm{C}$ for 24 hours, pulverized using Cyclotec mill then kept in an air-tight container and stored at $5^{\circ} \mathrm{C}$ until further analysis. A $500 \mathrm{~g}$ of the resulting powder was extracted through maceration with methanol for 72 hours then concentrated using a rotary evaporator at $40^{\circ} \mathrm{C}$. The peel crude extract was obtained and stored at $5^{\circ} \mathrm{C}$ until further 
analysis.

\subsection{Physicochemical evaluation}

The physicochemical characteristics of powdered peel and extract were determined as per WHO guidelines ${ }^{(6)}$. Parameters evaluated include the color, odor, taste, appearance, $\mathrm{pH}$, specific gravity, moisture content, ash content and aqueous solubility.

\subsection{Phytochemical screening}

The peel crude extract was qualitatively tested to reveal the presence of phytochemical constituents such as alkaloids, coumarins, flavonoids, phenols and triterpenoids. These were identified by characteristic color changes (chemical-based) using previously reported procedure ${ }^{(7)}$.

\subsection{Determination of proximate, heavy metal, mineral and vitamin content}

Analyses on proximate, heavy metal, mineral and vitamin composition of $H$. polyrhizus peel were performed at the Standards and Testing Division, Department of Science and Technology - Industrial Technology Development Institute (DOST-ITDI), Bicutan, Taguig, Metro Manila, Philippines using AOAC official method ${ }^{(8)}$. Briefly, the AOAC official method numbers 923.09 and 985.29 were used to analyze total sugar and total dietary fiber, respectively. Analyses were conducted by block digestionKjeldahl for crude protein, acid hydrolysis for total fat, gas chromatography for saturated fat, and by calculation for total carbohydrate and for food energy. Trace amounts of lead, cadmium, and chromium were determined according to the AOAC official method number 999.11. The hydride vapor generator atomic absorption spectrometry was used for detection of arsenic content. The AOAC official method number 969.32 was used in the detection of calcium, magnesium, sodium, iron, potassium, manganese and high-performance liquid chromatography for vitamin $\mathrm{C}$ analysis. The results were expressed by calculating the mean values obtained in each analysis.

\subsection{DPPH radical scavenging assay}

Antioxidant radical scavenging activity was determined by DPPH (2,2-diphenyl-1-picrylhydrazyl) assay. The assay was performed as previously described ${ }^{(9)}$ with minor modification. DPPH $0.1 \mathrm{mM}$ was prepared with methanol. Then, $1.5 \mathrm{ml}$ of various concentration of peel extract in methanol $(50 \mu \mathrm{g} / \mathrm{mL}-500 \mu \mathrm{g} / \mathrm{mL})$ were pipetted into $1.5 \mathrm{ml}$ DPPH solution and mixed. After incubation for 30 minutes in a dark place at room temperature, the absorbance was read against a control at 517 $\mathrm{nm}$. Inhibition of free radical by DPPH in percent (\%) is calculated using the following formula: Inhibition (\%) $=\left[\mathrm{A}_{\text {control }}\right.$ $\left.\mathrm{A}_{\text {sample }} / \mathrm{A}_{\text {control }}\right] \mathrm{x} 100$, where $\mathrm{A}_{\text {control }}$ is the absorbance of the control reaction (containing all reagents except the test sample), and $\mathrm{A}_{\text {sample }}$ is the absorbance of the test sample. The concentration that provides $50 \%$ inhibition ( $\mathrm{IC}_{50}$ ) expressed in $\mu \mathrm{g} / \mathrm{mL}$ was calculated against test sample concentration. Ascorbic acid was used as the positive control.

\subsection{Ferric reducing capacity assay}

The ferric reducing capacity (FRC) assay is based on the formation of $\mathrm{Fe}^{\mathrm{III}}-(\mathrm{Phen})_{3}$ complex and its disruption in the presence of reducing agents ${ }^{(10)}$. It is similar to the FRAP assay except the use of 1, 10-phenanthroline instead of TPTZ (2,4,6-tri-pyridyls-triazine $)^{(11)}$. The FRC of $H$. polyrhizus peel extract as antioxidant was determined according to the method described with slight modifications ${ }^{(12)}$. The reaction mixture containing $0.6 \mathrm{~mL} 0.05 \%$ O-phenanthroline in methanol, $1.2 \mathrm{~mL} 200 \mathrm{mM}$ ferric chloride, and $1.2 \mathrm{~mL}$ extract at various concentrations ranging from $50 \mu \mathrm{g} / \mathrm{mL}$ to $500 \mu \mathrm{g} / \mathrm{mL}$ in a final volume of $3 \mathrm{ml}$ was incubated for 10 minutes at room temperature. Then, the absorbance of the reaction mixture was read at $510 \mathrm{~nm}$. An increase in the absorbance of the reaction mixture indicated increased reducing capacity. Ascorbic acid was used as positive control.

\subsection{Data analysis}

All analyses for antioxidant activities (DPPH and FRC assays) were carried out in triplicates and data reported are mean \pm standard deviation (SD). All statistical analyses including computation of $\mathrm{IC}_{50}$ values were performed using GraphPad Prism 9.0 . 


\section{Results and Discussion}

\subsection{Physicochemical evaluation}

Table 1. Physicochemical Characteristics of H. polyrhizus

\begin{tabular}{lll}
\hline Parameter & Peel Powder & Methanol Peel Extract \\
\hline Color & Dark pink & Red purple \\
Appearance & Fibrous powder & Gummy \\
Odor & Indistinct & Indistinct \\
Taste & Acidic & Acidic \\
pH & 5 & 4.8 \\
Specific gravity & - & 1.1361 \\
Moisture content & $67.2 \mathrm{mg} / \mathrm{g}$ & - \\
Ash content & $147 \mathrm{mg} / \mathrm{g}$ & - \\
Aqueous solubility & Very slightly soluble & Freely soluble \\
\hline
\end{tabular}

The peel powder's water solubility is a consideration in establishment of a suitable formulation strategy in product development. Peel powder was very slightly soluble (1:1000-10000) to water while the peel crude extract was freely soluble (1:1). The peel powder's low moisture content implies its stability for a longer period and less susceptibility to microbial contamination ${ }^{(13)}$. The peel powder's ash content represents $14.7 \%$ of the total sample is greater than the $14 \%$ maximum acceptable limit recommended by European Pharmacopoeia ${ }^{(14)}$. The relatively high ash content value can be attributed to the presence of certain minerals ${ }^{(15)}$. The $\mathrm{pH}$ and specific gravity of the extract were also recorded as shown in Table 1.

\subsection{Phytochemical screening}

The presence of constituents such as alkaloids, coumarins, flavonoids, phenols, and triterpenoids in H. polyrhizus peel (Table 2), suggests its potential medicinal and nutritional applications. Alkaloids showed wide variety of biological activities including antihypertensive, antiarrhythmic, antimalarial activity, anticancer actions and among others ${ }^{(16)}$. Coumarin derivatives from other plants have shown potential as a skin whitening agent ${ }^{(17)}$ while p-coumaric acid could also attenuate skin hyperpigmentation ${ }^{(18)}$. Besides the antioxidant effect of flavonoids, there is also a growing evidence of the versatile health benefits which includes anti-inflammatory ${ }^{(19)}$, anti-proliferative and anticancer activity ${ }^{(20)}$, antihypertensive effects, coronary heart disease prevention ${ }^{(21)}$ and anti-human immunodeficiency virus functions ${ }^{(22)}$. Similarly, phenolic compounds are known for their chemo-preventive properties such as antioxidant, anticarcinogenic, antimutagenic, and anti-inflammatory effects ${ }^{(23)}$. These constituents in the peel extracts may act synergistically or antagonistically to produce biological activities and health benefits.

\subsection{Heavy Metals, Nutritional, Minerals, and Vitamin Composition}

In parallel with the increasing interest in the health benefits of $H$. polyrhizus peel, safety concerns are also recognized. The concentrations of arsenic, lead, cadmium, and chromium for the tested peel powder were found to be $0.22 \mathrm{mg} / \mathrm{kg}, 0.068 \mathrm{mg} / \mathrm{kg}$, $0.0225 \mathrm{mg} / \mathrm{kg}$, and $0.887 \mathrm{mg} / \mathrm{kg}$ respectively, which were all within the maximum permissible limit set by the WHO for herbal medicines ${ }^{(6)}$.

On the other hand, the crude protein content of the dragon fruit peel which is $42.8 \mathrm{mg} / \mathrm{g}$ may be useful in food formulation systems $^{(24)}$. Generally, fruits contain low amounts of fat. Total fat includes all types of dietary fat, which is equivalent to 5.26 $\mathrm{mg} / \mathrm{g}$ in the fruit peel and a saturated fat of $2.26 \mathrm{mg} / \mathrm{g}$. The total carbohydrate is the combined amount of all three types of carbohydrate namely, starch, sugar and fiber. From the total carbohydrate content, $5.05 \%$ is the total sugar which is lower than the result obtained by other study which is $8.4 \%$ and were identified mainly as glucose, fructose and maltose ${ }^{(25)}$. The high content in the peel powder's total dietary fiber may help in the maintenance of human health. Fiber decreases the risks of constipation by increasing stool bulk ${ }^{(26)}$ and known to reduce cholesterol level of the body ${ }^{(27)}$. Generally, the fruit peel had relatively high calories of nutritive value $(317 \mathrm{kCal} / 100 \mathrm{~g})$ that could provide health benefits.

H. polyrhizus peel powder contained certain concentrations of minerals (Table 3) which may support a wide range of potential health benefits. Among the tested macro elements, potassium was highest followed by $\mathrm{Ca}, \mathrm{Mg}$ and $\mathrm{Na}$ while $\mathrm{Mn}$ was higher than Fe in microelements. Potassium and sodium play roles in the maintenance of human normal physiology ${ }^{(28,29)}$. 
Table 2. Phytochemical Components of H. polyrhizus

\begin{tabular}{lll}
\hline Phytochemical & Test & Result \\
\hline Alkaloid & Wagner & + \\
Phytosterols & Libermann-Burchard & - \\
Tannins & Ferric Chloride & - \\
Phenols & Lead acetate & + \\
Flavonoids & Alkaline reagent & + \\
Coumarins & $10 \%$ Sodium hydroxide & + \\
Saponins & Froth & - \\
Quinones & Sulphuric acid & - \\
Cardiac Glycosides & Keller-Killani & - \\
Triterpenoids & Salkowski & + \\
Anthraquinones & $2 \%$ HCl & - \\
Steroids and Phytosteroids & Chloroform + sulphuric acid & - \\
\hline
\end{tabular}

(+) presence

(-) absence

However, too much sodium in the diet causes an increase in blood pressure ${ }^{(30)}$. In contrast, reduced blood pressure is linked to increased potassium intakes which may be due to potassium's ability to increase sodium excretion and the vasoactive effects of potassium on blood vessels ${ }^{(29)}$.

Table 3. Proximate composition of $H$. polyrhizus peel powder

\begin{tabular}{ll}
\hline Composition & Amount per 1 gram \\
\hline Crude Protein (Nx6.25) & $42.8 \mathrm{mg}$ \\
Total Fat & $5.26 \mathrm{mg}$ \\
Saturated Fat & $2.26 \mathrm{mg}$ \\
Total Carbohydrate & $738 \mathrm{mg}$ \\
Total Sugar & $37.3 \mathrm{mg}$ \\
Total Dietary Fiber & $632 \mathrm{mg}$ \\
Food Energy & $317 \mathrm{Kcal} / 100 \mathrm{~g}$ \\
\hline
\end{tabular}

The low sodium and relatively high potassium concentrations obtained from this study suggest that the consumption of dragon fruit peel is tolerable to hypertensive patients requiring low sodium diet. The presence of $49 \mathrm{mg} / \mathrm{kg} \mathrm{Vitamin} \mathrm{C} \mathrm{in} \mathrm{the} \mathrm{dragon} \mathrm{fruit}$ peel contributed for its acidic taste (Table 4 ). Numerous researches have shown that an adequate intake of vitamin $\mathrm{C}$ assumes a beneficial role in lowering the risk of developing cancers ${ }^{(31)}$ and prevention of diseases ${ }^{(32)}$.

Table 4. Mineral content per 1 gram of $H$. polyrhizus peel powder

\begin{tabular}{ll}
\hline Minerals & Amount per 1 gram \\
\hline Calcium & $9.56 \mathrm{mg}$ \\
Magnesium & $3.79 \mathrm{mg}$ \\
Sodium & $0.83 \mathrm{mg}$ \\
Iron & $0.023 \mathrm{mg}$ \\
Potassium & $54.4 \mathrm{mg}$ \\
Manganese & $0.11 \mathrm{mg}$ \\
Vitamin C & $49 \mathrm{mg} / \mathrm{kg}$ \\
\hline
\end{tabular}




\subsection{DPPH Antioxidant Activity}

H. polyrhizus peel extract and the positive control ascorbic acid exhibited a concentration dependent DPPH radical inhibition (Figure 1). This represents that an increased amount of antioxidant in a given volume of peel extract is responsible for the increased reduction of the DPPH solution ${ }^{(33)}$. In this study, H. polyrhizus peel extract exhibited the minimum activity of $11.77 \%$ at $50 \mu \mathrm{g} / \mathrm{mL}$ and the maximum activity of $39.24 \%$ at $500 \mu \mathrm{g} / \mathrm{mL}$. The $\mathrm{IC}_{50}$ value obtained by interpolation from linear regression analysis was $986.8 \mu \mathrm{g} / \mathrm{mL}$ which is comparative with the $\mathrm{IC}_{50}=994.25 \pm 29.63 \mu \mathrm{g} / \mathrm{mL}$ of $95 \%$ aqueous ethanol dragon fruit peel extract in Taiwan ${ }^{(34)}$. These values were higher in comparison with the other peel extracts using $70 \%$ ethanol $(0.30 \pm 0.01$ $\mathrm{mg} / \mathrm{mL})$ in Malaysia ${ }^{(35)}$ and both ethanol $\mathrm{HCl}(159.6 \mu \mathrm{g} / \mathrm{mL})$ and ethyl acetate $(648.9 \mu \mathrm{g} / \mathrm{mL})$ in Indonesia following DPPH assay ${ }^{(36)}$. The data suggest the considerable impact of geographical distributions, solvents and extraction procedures on the antioxidant activity of the $H$. polyrhizus peel.

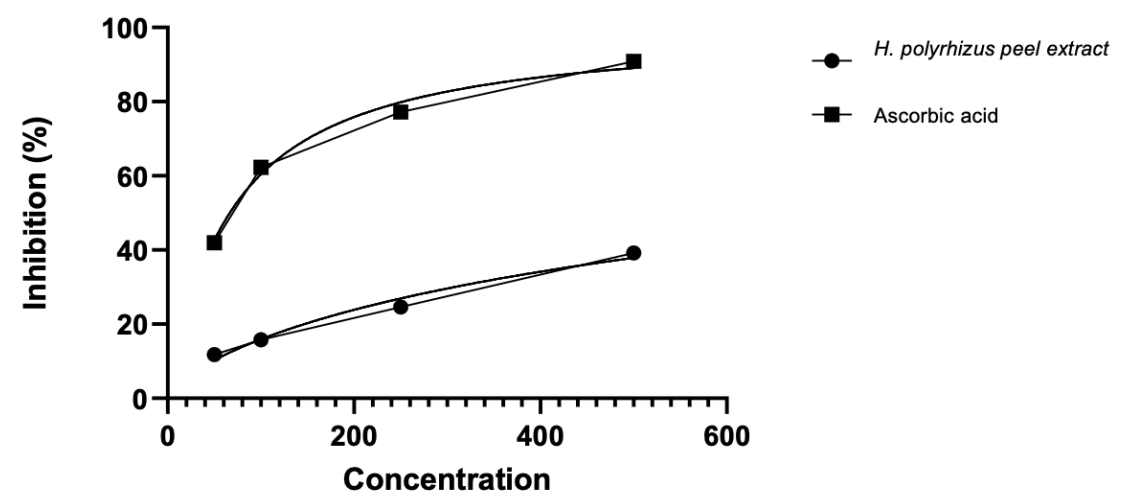

Fig 1. DPPH radical scavenging activities of $H$. polyrhizus peel extract and ascorbic acid at different concentrations $(50,100,250,500 \mu \mathrm{g} / \mathrm{mL})$. Values are expressed as the mean \pm standard deviation $(n=3)$ of the inhibition percentage.

\subsection{Ferric Reducing Capacity}

As secondary antioxidant, $H$. polyrhizus peel extract and ascorbic acid showed dose dependent ferric reducing capacity (Figure 2). A gradual increase in the absorbance of $H$. polyrhizus peel extract at $510 \mathrm{~nm}$ ranging from $0.032 \pm 0.002$ to $0.079 \pm 0.002$ was observed as the concentration increased from $50 \mu \mathrm{g} / \mathrm{mL}$ to $500 \mu \mathrm{g} / \mathrm{mL}$. Similarly, higher absorbance of ascorbic acid ranged from $0.073 \pm 0.001$ to $0.124 \pm 0.001$ which indicated reduction of ferric ions to ferrous ions ${ }^{(37,38)}$. Hence, the peel extract of dragon fruit may act as electron donors ${ }^{(39)}$ in a sufficient amount and could react with free radicals to convert them into more stable products thus decreasing the extent of Fenton reaction which is implicated in many diseases ${ }^{(33)}$.

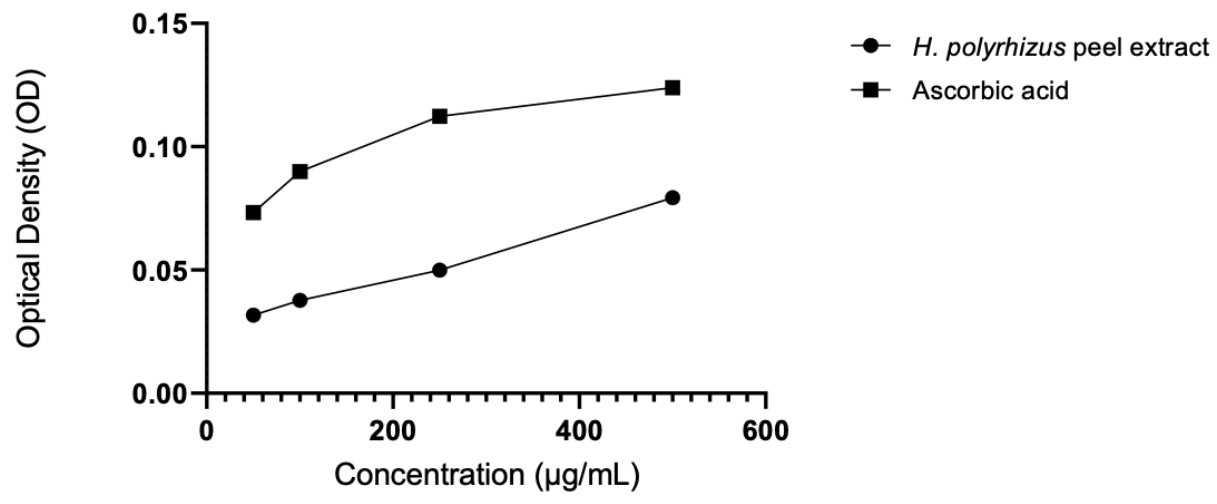

Fig 2. FRC of $H$. polyrhizus peel extract and ascorbic acid at different concentrations (50, 100, 250, 500 $\mu \mathrm{g} / \mathrm{mL})$. Values are expressed as the mean \pm standard deviation $(n=3)$ of the OD. 


\section{Conclusion}

The H. polyrhizus peel contained important phytochemical constituents that can exhibit biological activities. The quantitative and qualitative values detected in different analyses were all within acceptable limits and therefore, it is suggested as a potential source of micro and macronutrients, vitamin $\mathrm{C}$ and antioxidants that could be of nutritional and health benefits. Thus, $H$. polyrhizus peel can be considered in the development and formulation of natural health products.

\section{Acknowledgement}

The authors gratefully acknowledge the research fund and support provided by the Commission on Higher Education of the Philippines and the Mariano Marcos State University.

\section{References}

1) Pascua LT, Pascua ME, Gabriel M. Dragon fruit production and marketing in the Philippines: Its status, constraints and prospects. In: Jiang YL, Liu PC, Huang PH, et al., editors. Improving Pitaya Production and Marketing . 2012;p. 47-63. Available from: https://www.fftc.org.tw/htmlarea_file/activities/ 20150817121105/05-15P10.pdf.

2) Perween T, Mandal K, Hasan M. Dragon fruit: An exotic super future fruit of India. J Pharmacogn Phytochem. 2018;7(2):1022-1028. Available from: http://www.phytojournal.com/archives/2018/vol7issue2/PartO/7-1-435-453.pdf.

3) Tagay AA. Supply chain analysis of dragon fruit in Ilocos Norte, Philippines. International Journal of Engineering Researches and Management Studies. 2017;4(4):11-27. Available from: https://www.ijerms.com/DOC/Isuespdf/Archive-2017/April-2017/3.pdf.

4) Pathak PD, Mandavgane SA, Kulkarni BD. Fruit peel waste as a novel low-cost bio adsorbent. Reviews in Chemical Engineering. 2015;31(4):361-381. Available from: https://dx.doi.org/10.1515/revce-2014-0041.

5) Khattak KF, Taj-Ur-Rahman. Effect of geographical distributions on the nutrient composition, phytochemical profile and antioxidant activity of Morus nigra. Pak J Pharm Sci. 2015;28(5):1671-1679. Available from: http://www.pjps.pk/wp-content/uploads/pdfs/28/5/Paper-16.pdf.

6) WHO. Quality control methods for herbal materials. World Health Organization. 2011.

7) Luo H, Cai Y, Peng Z, Liu T, Yang S. Chemical composition and in vitroevaluation of the cytotoxic and antioxidant activities of supercritical carbon dioxide extracts of pitaya (dragon fruit) peel. Chemistry Central Journal. 2014;8(1):1-7. Available from: https://dx.doi.org/10.1186/1752-153x-8-1.

8) AOAC (Association of Official Analytical Chemistry). In: and others, editor. Official methods of analysis. Gaithersburg. 2012.

9) Karagöz A, Artun FT, Özcan G, Melikoğlu G, Anıl S, Kültür Ş, et al. In vitroevaluation of antioxidant activity of some plant methanol extracts. Biotechnology \& Biotechnological Equipment. 2015;29(6):1184-1189. Available from: https://dx.doi.org/10.1080/13102818.2015.1080600.

10) Benzie IFF, Strain JJ. The Ferric Reducing Ability of Plasma (FRAP) as a Measure of "Antioxidant Power": The FRAP Assay. Analytical Biochemistry. 1996;239(1):70-76. Available from: https://dx.doi.org/10.1006/abio.1996.0292.

11) Lim C, Lim SL. Ferric Reducing Capacity Versus Ferric Reducing Antioxidant Power for Measuring Total Antioxidant Capacity. Lab Med. 2013;44(1):5156. doi:10.1309/LM93W7KTFNPZIXRR.

12) Amudha M, Rani S. Evaluation of In Vitro Antioxidant Potential of Cordia retusa. Indian Journal of Pharmaceutical Sciences. 2016;78(1):80-86. Available from: https://dx.doi.org/10.4103/0250-474x.180253.

13) Hell K, Mutegi C. Aflatoxin control and prevention strategies in key crops of Sub-Saharan Africa. Afr J Microbiol Res. 2011;5(5):459-66. Available from: http://crsps.net/wp-content/downloads/Peanut/Inventoried\%208.8/7-2011-4-142.pdf.

14) Vaikosen EN, Alade GO. Evaluation of pharmacognostical parameters and heavy metals in some locally manufactured herbal drugs. J Chem Pharm Res. 2011;3(2):88-97.

15) Mukherjee PK. Qualitative Analysis for Evaluation of Herbal Drugs. In: and others, editor. Evaluating Natural Products and Traditional Medicine. Elsevier. 2019;p. 79-149.

16) Thawabteh A, Juma S, Bader M, Karaman D, Scrano L, Bufo S, et al. The Biological Activity of Natural Alkaloids against Herbivores, Cancerous Cells and Pathogens. Toxins. 2019;11(11):1-28. Available from: https://dx.doi.org/10.3390/toxins11110656.

17) Tenore GC, Novellino E, Basile A. Nutraceutical potential and antioxidant benefits of red pitaya (Hylocereus polyrhizus) extracts. Journal of Functional Foods. 2012;4(1):129-136. Available from: https://dx.doi.org/10.1016/j.jff.2011.09.003.

18) Boo YC. Coumaric acid as an active ingredient in cosmetics: A review focusing on its antimelanogenic effects. Antioxidants. 2019;8(8):1-16. Available from: https://doi.org/10.3390/antiox8080275.

19) Maleki SJ, Crespo JF, Cabanillas B. Anti-inflammatory effects of flavonoids. Food Chemistry. 2019;30(299). Available from: https://dx.doi.org/10.1016/j. foodchem.2019.125124.

20) de Souza PO, Bianchi SE, Figueiró F, Heimfarth L, Moresco KS, Gonçalves RM, et al. Anticancer activity of flavonoids isolated from Achyrocline satureioides in gliomas cell lines. Toxicology in Vitro. 2018;51:23-33. Available from: https://dx.doi.org/10.1016/j.tiv.2018.04.013.

21) Ellwood L, Torun G, Bahar Z, Fernandez R. Effects of flavonoid rich fruits on hypertension in adults: A systematic review. JBI Database of System Rev Implement Rep. 2019;17(10):2075-2105. doi:10.11124/JBISRIR-D-19-00050.

22) Murata RM, Pasetto S, Pardi V. The anti-HIV activity of flavonoids: Quercetin and Pinocembrin. Planta Medica. 2014;80(10):PE9. Available from: https://dx.doi.org/10.1055/s-0034-1382573.

23) da Silva Haas IC, Marmitt DJ, Fedrigo IMT, Goettert MI, Bordignon-Luiz MT. Evaluation of antiproliferative and anti-inflammatory effects of non-pomace sediment of red grape juices (Vitis labrusca L.) in healthy and cancer cells after in vitro gastrointestinal simulation. PharmaNutrition. 2020;13. Available from: https://dx.doi.org/10.1016/j.phanu.2020.100204.

24) Kassegn HH. Determination of proximate composition and bioactive compounds of the Abyssinian purple wheat. Cogent Food \& Agriculture. 2018;4(1):19. Available from: https://dx.doi.org/10.1080/23311932.2017.1421415.

25) Jamilah B, Shu CE, Kharidah M, Dzulkifly MA, Noranizan A. Physico-chemical characteristics of red pitaya (Hylocereus polyrhizus). International Food Research Journal;18:279-286. Available from: http://psasir.upm.edu.my/id/eprint/16208/1/16208.pdf. 
26) Caprita A, Caprita R, Simulescu V, Drehe R. The effect of temperature on soluble dietary fiber fraction in cereals. J Agroaliment Processes Technol. 2011;17(3):214-231.

27) Soliman GA. Dietary Fiber, Atherosclerosis, and Cardiovascular Disease. Nutrients. 2019;11(5):1-11. Available from: https://dx.doi.org/10.3390/ nu11051155.

28) Stamler J, Chan Q, Daviglus ML, Dyer AR, Horn LV, Garside DB, et al. Relation of Dietary Sodium (Salt) to Blood Pressure and Its Possible Modulation by Other Dietary Factors. Hypertension. 2018;71(4):631-637. Available from: https://dx.doi.org/10.1161/hypertensionaha.117.09928.

29) Muhammad I, Ashiru S, Ibrahim I, Kanoma I, Sani I, Garba S. Effect of ripening stage on vitamin C content in selected fruits. Int J Agric For Fish. 2014;2(3):60-65.

30) Dong OM. Excessive dietary sodium intake and elevated blood pressure: a review of current prevention and management strategies and the emerging role of pharmaconutrigenetics. BMJ Nutr Prev Health. 2018;1(1):7-16.

31) Rahman MM, Khan MMR, Hosain MM. Analysis of vitamin C (ascorbic acid) contents in various fruits and vegetables by UV-spectrophotometry. Bangladesh Journal of Scientific and Industrial Research. 2007;42(4):417-441.

32) Grosso G, Bei R, Mistretta A, Marventano S, Calabrese G, Masuelli L. Effects of vitamin C on health: A review of evidence. Front Biosci. 2013;18(3):10171046.

33) Choo WS, Yong WK. Antioxidant properties of two species of Hylocereus fruits. Adv Appl Sci Res. 2011;2(3):418-443.

34) Tsai Y, Lin CG, Chen WL, Huang YC, Chen CY, Huang KF. Evaluation of the antioxidant and wound-healing properties of extracts from different parts of Hylocereus polyrhizus. Agronomy. 2019;9(1):1-10. Available from: https://doi.org/10.3390/agronomy9010027.

35) Nurliyana R, Zahir IS, Suleiman KM, Aisyah MR, Rahim KK. Antioxidant study of pulps and peels of dragon fruits: A comparative study. Int Food Res J. 2010;17(2):367-375.

36) Hendra R, Masdeatresa L, Abdulah R, Haryani Y. Red dragon peel (Hylocereus polyrhizus) as antioxidant source. AIP Conference Proceedings. 2020;2243:10-14. doi:10.1063/5.0001391.

37) Zhang Q, Shao J, Zhao T, He L, Ma H, Jing L. The Role of C-8 OH on the Antioxidant Activity of Norwogonin and Isowogonin. Natural Product Communications. 2020;15(5):1-7. Available from: https://dx.doi.org/10.1177/1934578x20924887.

38) Amadou I, Le GW, Shi YH, Jin S. Reducing, Radical Scavenging, and Chelation Properties of Fermented Soy Protein Meal Hydrolysate byLactobacillus plantarumLP6. International Journal of Food Properties. 2011;14(3):654-665. Available from: https://dx.doi.org/10.1080/10942910903312502.

39) Gülçin I. Fe3+-Fe2+ transformation method: An important antioxidant assay. In: D A, editor. Advanced Protocols in Oxidative Stress III Methods in Molecular Biology . Humana Press. 2014;p. 1-477. doi:10.1007/978-1-4939-1441-8_17. 